\title{
ANALISIS INDEKS KEPUASAN MASYARAKAT TERHADAP PELAYANAN DI UNIT RAWAT JALAN RSUD KOTA BENGKULU
}

\author{
Nofri Heltiani, Yunita Resti \\ Akademi Kesehatan Sapta Bakti Bengkulu
}

\begin{abstract}
ABSTRAK
Indeks Kepuasan Masyarakat merupakan data dan informasi tentang tingkat kepuasan masyarakat yang diperoleh dari hasil pengukuran kuantitatif dan kualitatif atas pendapat masyarakat dalam memperoleh pelayanan kesehatan. Upaya peningkatan kualitas adalah langkah terpenting untuk meningkatkan daya saing usaha pemerintah maupun swasta dibidang kesehatan, karena kesehatan merupakan salah satu hak dasar rakyat sesuai amanat UUD 1945 Pasal $28 \mathrm{H}$ ayat (1). Tujuan penelitian ini adalah untuk mengetahui indeks kepuasan masyarakat terhadap pelayanan di unit rawat jalan RSUD Kota Bengkulu. Jenis penelitian yang digunakan pada penelitian ini adalah deskriptif kuantitatif dengan pendekatan cross sectional, populasi dalam penelitian ini adalah pasien yang datang dan berobat di unit rawat jalan RSUD Kota Bengkulu, dengan sampel sebanyak 80 pasien yang datang dan berobat di unit rawat jalan RSUD Kota Bengkulu dengan teknik pengambilan sampel accidental sampling. Menggunakan data primer, diolah menggunakan rumus pengukuran Indeks Kepuasan Masyarakat berdasarakan Keputusan Menteri Aparatur Negara Nomor 25 Tahun 2004. Penelitian ini dilaksanakan pada bulan Juli di unit rawat jalan RSUD Kota Bengkulu. Hasil analisa data dari tujuh indikator kepuasan yang diukur yaitu kejelasan petugas pelayanan 2.99 (puas), kedisiplinan petugas pelayanan 2.95 (puas) kecepatan pelayanan 2.48 (cukup puas), keadilan mendapatkan pelayanan 2.53 (puas), kesopanan dan keramahan 2.88 (puas), kepastian jadwal pelayanan 2.75 (puas) dan kenyaman lingkungan 2.94 (puas). Diharapkan Para pejabat RSUD Kota Bengkulu perlu kiranya menetapkan target bahwa indeks kinerja di masing-masing unit pelayanan tidak lagi memiliki kinerja yang cukup baik, akan tetapi semua unit pelayanan memiliki komitmen untuk mencapai kinerja pelayanan yang optimal (sangat baik).
\end{abstract}

\section{PENDAHULUAN}

Upaya peningkatan kualitas pelayanan

kesehatan adalah langkah terpenting untuk meningkatkan daya saing usaha pemerintah maupun swasta di sektor kesehatan. Selain itu karena kesehatan merupakan salah satu hak dasar rakyat, yaitu memperoleh pelayanan kesehatan sesuai dengan UUD 1945 Pasal $28 \mathrm{H}$ ayat (1). Sesuai dengan Buku Pegangan Penyelenggara Pemerintah dan Pembangunan Daerah yang dikeluarkan oleh Bappenas 2006, maka pemerintah daerah atau instansi yang menyedikan pelyanan terhadap publik perlu melakukanperbaikan terhadap sistem pelayanan. Ini harus dilakukan untuk menciptakan perubahan pelayanan dalam rangka desentralisasi. Mekanisme apa yang perlu dilakukan dalam reformasi pelayanan publik, pemerintah melalui Keputusan Menteri Pendayagunaan Aparatur Negara Nomor 25 Tahun 2004 Tentang Pedoman Umum Penyusunan Indeks Kepuasan Masyarakat Unit Pelayanan Instansi Pemerintah mengintruksikan pemerintah daerah atau instansi untuk menilai seberapa besar 
kepuasan dari masyarakat terhadap layaan yang diberikan. Rumah Sakit Umum Daerah (RSUD) Kota Bengkulu yang beralamatkan Jalan Basuki Rahmat Kota Bengkulu adalah salah satu penyedia layanan kesehatan publik di Kota Bengkulu yang memberikan pelayanan kesehatan kepada masyarakat Bengkulu yang mulai beroperasi sejak Januari 2014. Sebagai rumah sakit milik pemerintah RSUD Kota Bengkulu terus berbenah diri, baik dari segi Sumber Daya Manusia (SDM), fasilitas kesehatan serta sarana gedung dan transportasi. RSUD Kota Bengkulu juga melayani pasien asurasi dan umum, dengan jumlah kunjungan pasien per-harinya \pm 100 orang pasien. Berdasarkan studi pendahuluan yang telah dilakukan di RSUD Kota Bengkulu pada bulan Maret 2017 dengan menggunakan kuesioner 14 indikator unsur penilaian berdasarkan Keputusan Menteri Pendayagunaan Aparatur Negara Nomor 25 Tahun 2004 yang disebarkan pada pasien yang datang dan berobat di Unit Rawat Jalan RSUD Kota Bengkulu diperoleh data dari 10 kuesioner yang disebarkan $60 \%$ menyatakan cukup puas pada prosedur pelayanan, $50 \%$ menyatakan tidak puas pada persyaratan pelayanan, $60 \%$ menyatakan tidak puas pada kejelasan petugas pelayanan, $60 \%$ menyatakan tidak puas pada kedisiplinan petugas pelayanan, $60 \%$ menyatakan cukup puas pada tanggung jawab pelayanan, $70 \%$ menyatakan cukup puas pada kemampuan petugas pelayanan, 60\% menyatakan tidak puas pada kecepatan pelayanan, $70 \%$ menyatakan cukup puas pada keadilan mendapatkan pelayanan, 50\% menyatakan cukup puas pada kesopanan dan keramahan petugas pelayanan, $60 \%$ menyatakan tidak puas pada kewajaran biaya pelayanan, $60 \%$ menyatakan tidak puas pada kepastian biaya pelayanan, $70 \%$ menyatakan cukup puas pada kepastian jadwal pelayanan, 60\% menyatakan cukup puas pada kenyaman lingkungan serta 60\% menyatakan cukup puas pada keamanan pelayanan. Untuk mengetahui sejauh mana kualitas pelayanan di RSUD Kota Bengkulu maka perlu diselenggarakan survei pendapat tentang kepuasan layanan kesehatan terhadap pelayanan yang diberikan oleh pihak rumah sakit. Caranya dengan melakukan Studi Indeks Kepuasan Masyarakat. Studi Indeks Kepuasan Masyarakat merangkum data dan informasi tentang tingkat kepuasan masyarakat yang diperoleh dari hasil pengukuran secara kuantitatif dan kualitatif atas pendapat masyarakat dalam memperoleh pelayanan dari aparatur penyelenggara pelayanan publik dengan membandingkan antara harapan dan kebutuhannya. Hasil survei sangat penting 
sebagai bahan evaluasi dan bahan masukan bagi pihak rumah sakit untuk terus-menerus melakukan perbaikan sehingga kualitas pelayanan terbaik dapat segera dicapai, dan akhirnya dapat memenuhi harapan dan tuntutan masyarakat terhadap pelayanan kesehatan yang bermutu tinggi. Maka dari itu penulis tertarik untuk menelti tentang "Analisis Indeks Kepuasan Masyarakat Terhadap Pelayanan di Unit Rawat Jalan RSUD Kota Bengkulu". Peneliti ini bertujuan untuk mengetahui Diketahui indeks kepuasan masyarakat terhadap pelayanan di unit rawat jalan RSUD Kota Bengkulu.

\section{METODE PENELITIAN}

Penelitian ini menggunakan jenis penelitian deskriptif kuantitatif dengan pendekatan cross sectional. Populasi penelitian ini yaitu pasien yang datang dan berobat di Unit Rawat Jalan RSUD Kota Bengkulu. Teknik pengambilan sampel dalam penelitian ini adalah teknik accidental sampling. Jenis data penelitian ini yaitu teknik pengumpulan data yang digunakan adalah Data primer yang dimana data primer adalah data yang diperoleh secara langsung dari responden yaitu pasien yang datang dan berobat di Unit Rawat Jalan RSUD Kota Bengkulu. Setelah data terkumpul data disajikan dalam bentuk table dan narasi.

\section{HASIL PENELITIAN}

Tabel 1 Analisis Karakteristik Responden Indeks Kepuasan Masyarakat Terhadap Pelayanan di Unit Rawat Jalan RSUD Kota Bengkulu

\begin{tabular}{|c|c|c|c|}
\hline NO & KARAKTERISTIK & KETERANGAN & PERSENTASE (\%) \\
\hline \multirow[t]{3}{*}{1.} & \multirow[t]{3}{*}{ Umur } & Remaja (16 - 21 tahun) & 18.75 \\
\hline & & Dewasa (22 - 50 tahun) & 58.75 \\
\hline & & Lansia (>51 tahun) & 22.5 \\
\hline \multirow[t]{2}{*}{2.} & \multirow[t]{2}{*}{ Jenis Kelamin } & Laki-Laki & 43.75 \\
\hline & & Perempuan & 56.25 \\
\hline \multirow[t]{6}{*}{3.} & \multirow[t]{6}{*}{ Pendidikan } & SD/Sederajat & 23.75 \\
\hline & & SLTP/Sederajat & 8.75 \\
\hline & & SLTA/Sederajat & 31.25 \\
\hline & & Diploma III & 18.75 \\
\hline & & Sarjana (S1)' & 12.5 \\
\hline & & Pascasarjana (S2) & 5 \\
\hline \multirow[t]{2}{*}{4.} & \multirow[t]{2}{*}{ Pekerjaan } & PNS/TNI/Polri/Pensiunan & 16.25 \\
\hline & & Swasta/Karyawan & 22.5 \\
\hline
\end{tabular}




\begin{tabular}{|l|l|l|c|}
\hline \multirow{2}{*}{} & Wiraswasta/Pedagang & 22.5 \\
\cline { 3 - 4 } & & Petani/Nelayan & 2.5 \\
\cline { 3 - 4 } & IRT & 27.5 \\
\cline { 3 - 4 } & Lainnya & 8.75 \\
\hline 5. & Sumber Pembiayaan & Umum & 10 \\
\cline { 3 - 4 } & Asuransi & 90 \\
\hline
\end{tabular}

Dominasi responden berdasarkan karakteristik tersebut akan memberikan kontribusi terhadap 7 unsur pelayanan yang diteliti dalam penelitian ini. Nilai yang diperoleh RSUD Kota Bengkulu berdasarkan 80 kuesioner yang disebarkan dalam penelitian ini pada setiap unsurnya terlihat pada tabel di bawah ini.

Tabel 2 Analisis Indeks Kepuasan Masyarakat Terhadap Pelayanan di Unit Rawat Jalan RSUD Kota Bengkulu

\begin{tabular}{|c|l|c|c|}
\hline NO & \multicolumn{1}{|c|}{ INDIKATOR KEPUASAN } & INDEKS & \multirow{2}{*}{ KATAGORI } \\
\hline \hline 1. & Kejelasan Petugas Pelayanan & 2.99 & Puas \\
\hline 2. & Kedisiplinan Petugas Pelayanan & 2.95 & Puas \\
\hline 3. & Kecepatan Pelayanan & 2.48 & Cukup Puas \\
\hline 4. & Keadilan Mendapatkan Pelayanan & 2.53 & Puas \\
\hline 5. & Kesopanan dan Keramahan Petugas & 2.88 & Puas \\
\hline 6. & Kepastian Jadwal Pelayanan & 2.75 & Puas \\
\hline 7. & Kenyamanan Lingkungan & 2.94 & Puas \\
\hline
\end{tabular}

\section{PEMBAHASAN}

Berdasarkan hasil analisis pada tabel 2 dapat terlihat bahwa dari penilaian 7 unsur IKM pada pelayanan Unit Rawat Jalan di RSUD Kota Bengkulu, sebagaian besar unsur IKM mendapat nilai dengan kategori puas. Sedangkan untuk unsur yang memiliki nilai tertinggi adalah pada unsur kejelasan petugas pelayanan yaitu sebesar 2.99 dan unsur yang memiliki nilai terendah adalah pada unsur kecepatan pelayanan yaitu sebesar 2.48. Dari penelitian menunjukkan terdapat beberapa unsur yang memiliki nilai rata-rata dengan kategori puas. Oleh karena itu peneliti menyajikan beberapa unsur pelayanan yang perlu dipertahankan kualitas pelayanannya atau yang menjadi prioritas dalam rangka peningkatan kualitas pelayanan. Unsur pelayanan yang perlu dipertahankan dan/atau ditingkatkan kualitasnya merupakan unsur pelayanan yang mencapai nilai dengan kategori puas. Unsur pelayanan yang termasuk kategori ini adalah sebagai berikut.

1. Kejelasan Petugas Pelayanan

Unsur ini harus dipertahankan dan/atau ditingkatkan karena kejelasan untuk mendapatkan pelayanan dinilai tidak sulit oleh pasien, selain itu juga kejelasan 
untuk mendapatkan pelayanan juga sudah sesuai dengan standar pelayanan dari RSUD Kota Bengkulu. Unsur pelayanan ini memiliki kinerja pelayanan dalam kategori Puas.

\section{Kedisiplinan Petugas Pelayanan}

Unsur kedisiplinan petugas pelayanan memiliki kinerja pelayanan dengan kategori Puas, dimana pasien merasa kedisiplinan petugas telah memenuhi standar yang telah ditentukan. Tenaga medis maupun staf administrasi memberikan pelayanannya sesuai dengan jadwal atau jam kerja sesuai dengan yang telah ditentukan.

\section{Kecepatan Pelayanan}

Unsur kecepatan pelayanan mencapai nilai dengan kategori Cukup Puas dimana pelayanan yang diberikan oleh instalasi rawat jalan kepada pasien belum mencapai standar pelayanan yang ditentukan RSUD Kota Bengkulu.

\section{Keadilan Mendapatkan Pelayanan}

Unsur keadilan mendapatkan pelayanan termasuk dalam kategori Puas dimana dapat dijelaskan bahwa unsur pelayanan ini perlu untuk ditingkatkan waluapun petugas pelayanan dinilai oleh pasien sudah melakukan tugasnya secara adil pada pasien dengan tidak membedakan status dan golongan pasien.

\section{Kesopanan dan Keramahan Petugas}

Unsur pelayanan ini harus dipertahankan oleh pihak RSUD Kota Bengkulu karena sikap dan perilaku petugas dinilai oleh masyarakat dalam memberikan pelayanan sudah sopan dan saling menghargai terhadap pasien. Selain itu unsur ini juga memiliki kinerja pelayanan dengan kategori Puas.

\section{Kepastian jadwal Pelayanan}

Pasien beranggapan bahwa jadwal pelayanan di RSUD Kota Bengkulu sesuai dengan jadwal pelayanan yang telah ditentukan dan diberitahukan kepada pasien sehingga pasien tidak perlu untuk menunggu lama atau tidak memperoleh kepastian jadwal pelayanan sehingga nilai unsur pelayanan ini termasuk dalam kategori Puas.

\section{Kenyamanan Lingkungan}

Pelayanan di RSUD Kota Bengkulu dianggap telah memberikan kenyamanan kepada pasien dalam memperoleh pelayanan rawat jalan. Sehingga hal ini memberikan nilai kinerja pelayanan yang ditentukan standar pelayanan RSUD Kota Bengkulu sehingga tidak membebani pasien. Unsur ini termasuk dalam kategori Puas.

\section{SIMPULAN}


1. Indeks Kepuasan Masyarakat terhadap pelayanan di Unit Rawat Jalan RSUD Kota Bengkulu 2.79 dengan katagori Puas.

2. Indeks Kepuasan Masyarakat terhadap kejelasan pelayanan sebesar 2.99 dengan katagori puas.

3. Indeks Kepuasan Masyarakat terhadap kedisiplinan petugas pelayanan sebesar 2.95 dengan katagori puas.

4. Indeks Kepuasan Masyarakat terhadap kecepatan petugas pelayanan sebesar 2.48 dengan katagori cukup puas.

5. Indeks Kepuasan Masyarakat terhadap keadilan petugas pelayanan sebesar 2.53 dengan katagori puas.

6. Indeks Kepuasan Masyarakat terhadap kesopanan dan keramahan petugas pelayanan sebesar 2.88 dengan katagori puas.

7. Indeks Kepuasan Masyarakat terhadap kepastian jadwal pelayanan sebesar 2.75 dengan katagori puas.

8. Indeks Kepuasan Masyarakat terhadap kenyamanan pelayanan sebesar 2.94 dengan katagori puas.

\section{DAFTAR PUSTAKA}

Endah, R. 2008. Analisis Kualitas Layanan, Kualitas Produk dan Harga Terhadap Kepuasan Pelanggan. Skripsi, Universitas Diponegoro.

Keputusan Kementerian Pendayagunaan Aparatur Negara Nomor 63 Tahun 2003

\section{Tentang Pedoman Umum Penyelenggaraan Pelayanan Publik}

Keputusan Kementrian Pendayagunaan Aparatur Negara Nomor 25 Tahun 2004 Tentang Pedoman Penyusunan Indeks Kepuasan Masyarakat.

Kotler, P. 2005. Manajemen Pemasaran. Jakarta: Indeks.

Notoatmodjo, S. 2005. Metodelogi Penelitian Kesehatan. Jakarta: PT. Rineka Cipta.

Peraturan Pemerintah Nomor 65 Tahun 2005 Tentang Pedoman Penyusunan dan Penetapan Standar Pelayanan Minimal.

Rachmadi. 2008. Analisis Kuaitas Pelayanan Terhadap Kepuasan Pasien Rawat Inap Kelas III di RSUD Kabupaten Karimun. Tesis, Universitas Terbuka.

Sinambela, L. 2007. Reformasi Pelayanan Publik. Jakarta: Bumi Aksara.

Sugiyono. 2013. Metode Penelitian Kuantitatif Kualitatif dan R\&D. Banung: Alfabeta.

Supraptono, S. 1998. Analisis Kualitas Pelayanan dan Kepuasan Pasien Rawat Inap RSUD Dr. Murjani. Tesis, Universitas Gadjah Mada.

Undang-Undang Republik Indonesia Nomor 9 Tahun 1960 Tentang Pokok-Pokok Kesehatan.

Undang-Undang Republik Indonesia Nomor 25 Tahun 2000 Tentang Program Pembangunan Nasional.

Undang-Undang Republik Indonesia Nomor 25 Tahun 2009 Tentang Pelayanan Publik.

Undang-Undang Republik Indonesia Nomor 36 Tahun 2009 Tentang Kesehatan 
